\title{
APSKATI
}

http://doi.org/10.22364/adz.55.15

\section{VAI KARALIENE IR KAILA?}

\author{
Ainārs Dimants, Dr. phil., Biznesa augstskolas Turība profesors
}

Latvijas Republikas simtgades zīmē grāmatnīcās nonācis apjomīgs komunikācijas zinātnes pētījuma "ksieǵelis" - Latvijas mediju vides daudzveidība Vitas Zelčes zinātniskajā redakcijā (R̄̄ga: LU Akadēmiskais apgāds, 2018) ${ }^{1}$. Tā vāka noformējumā dominē fragmenti no pagātnes, nevis mūsdienu preses izdevumiem, liekot domāt, ka tēma tiks apskatīta vēsturiskā kontekstā.

Pirms tam pēdējoreiz š̄ tēma tik plaši apskatìta pirms pieciem gadiem - monogrāfiskajā politologa Jura Dreifelda rakstā Latvijas preses un citu plašsaziņas lìdzekl̦ attīstība 19.-21. gadsimtā krājuma Latvieši un Latvija 3. sējumā (Rīga: Latvijas Zinātṇu akadēmija, 2013). Uz to gan jaunajā kolektīvajā monogrāfijā nav atsauces. Toties simtgades zìmē nu klajā nācis arī Nacionālās enciklopēdijas sējums Latvija (Rīga: Latvijas Nacionālā bibliotēka, 2018) ar plašu nodaḷu Komunikācija ${ }^{2}$

1 Pieejams: https://www.szf.lu.lv/fileadmin/user upload/szf faili/Petnieciba/Latvijas-mediju-vides-daudzveidiba-small.pdf (26.10.2019.).

2 Pieejams: https://v.ejo-online.eu/5244/isas-zinas/ laista-klaja-nacionala-enciklopedija-tajaskirklis-ari-par-medijiem-un-komunikacijulatvija (26.10.2019.); https://enciklopedija.lv/ skirklis/21949-komunikācijas-politika-Latvijä (26.10.2019.); https://enciklopedija.lv/skirklis/ 22122-drukātā-prese-Latvijā (26.10.2019.); https://enciklopedija.lv/skirklis/21975-radio- un jau ceturtais ${ }^{3}$ un piektais ${ }^{4}$ izdevums ${ }^{5}$ Baltic Media Health Check ${ }^{6}$, ko atkal sagatavojis pētnieciskās žurnālistikas centrs Re:Baltica.

Vārdu sakot, ir ar ko salīdzināt, un uzprasās jautājums, vai karaliene - komunikācijas zinātne - ir kaila, proti, ko jaunu tā spējusi pienest Latvijas mediju vides daudzveidības noskaidrošanā? Diemžēl "kiieǵelis" izrādās sadrupis - tik retais par Latvijas nodokḷ maksātāju naudu (no Kultūras ministrijas)

Latvijā (26.10.2019.); https://enciklopedija.lv/ skirklis/21995-televīzija-Latvijā (26.10.2019.); https://enciklopedija.lv/skirklis/22137-tīmeklisLatvijā (26.10.2019.); https://enciklopedija.lv/ skirklis/22144-foto-un-zinu-aǵentūras-Latvijā (26.10.2019.); https://enciklopedija.lv/skirklis/ 5166-reklāma-un-sabiedriskās-attiecības-Latvijā (26.10.2019.).

3 Pieejams: https://www.sseriga.edu/sites/default/ files/inline-files/Baltic_media_health_check 2017-2018.pdf (26.10.2019.).

4 Pieejams: https://www.sseriga.edu/sites/default/ files/inline-files/Baltic\%20Media\%20Health\%20Check\%202018-2019.pdf (17.11.2019.).

5 Pieejams: https://lv.ejo-online.eu/3701/medijuzurnalistika/baltijas-mediju-veseliba-skaitli-runa-bet-diagnoze-nepilniga (26.10.2019.).

6 Pieejams: https://lv.ejo-online.eu/4670/petijumi/ mediji-latvija-prasa-pardomatu-mediju-politiku (26.10.2019.). 
finansētais komunikācijas zinātnes pētījums ir iznācis fragmentārs un pazudis momentuzṇēmuma kaleidoskopā.

\section{Stiprā puse}

Grāmatai ir monogrāfijas struktūra, tomēr 16 autoru sarakstìto nodaļu un apakšnodaḷu kvalitāte un saistība ar grāmatas kopējo konceptuālo uzbūvi ir izteikti nevienmērīga. It īpaši trīs pētniecībai izvirzīto kontekstu - organizatoriskā, radīšanas/ražošanas un produkcijas - nošķīrums ir acīmredzami nepietiekams jau pašā struktūrā.

Labā ziṇa, ka grāmatai ir izvēlēta skaidra koncepcija, izmantojot norvēǵu pētnieces Helles Ševogas (Helle Sjøvaag) pieeju mediju sistēmas ārējās un iekšējās daudzveidības apstākḷiem, kas teicami izklāstīta V. Zelčes ievadnodaḷā. Vienlaikus uzreiz jāatzīst, ka š̄ koncepcija ir vairāk aprakstoša, statiska, varētu pat teikt - garlaicīga, nevis problematizējoša, kaut vai salīdzinājumā ar vācu sociologa Niklasa Lūmana (Niklas Luhmann) funkcionāli strukturālo sistēmteoriju par plašsaziṇas (masu) mediju apakšsistēmu sabiedrības sistēmā (sal. nodaļu par Latviju citā 2018. gadā iznākušā grāmatā̄7).

Nodaḷā par mediju daudzveidības strukturālo kontekstu V. Zelče, patiesībā neejot tālāk par valdības politikas plānošanas dokumentā par mediju politikas pamatnostādnēm 2016.2020. gadam $^{8}$ noteikto, vismaz garāmejot, ar vienu teikumu pieskaras būtiskai Latvijas mediju ekonomikas un kvalitātes problēmai: "Spilgts sponsorētu mediju piemērs ir SIA Mediju nams, kura izdevumu vidū ir laikraksts Neatkarīgā Rìta Avīze, kurš darbojas savu ippašnieku un tiem tuvu stāvošu personu politiskajās un ekonomiskajās interesēs." Līdzīgi par pašvaldību izdevumiem (kā "hibrīdmedijiem"), kuri ir ne mazāka problēma. Tomēr salīdzinājumā ar iepriekš minētajiem Baltic Media Health Check izdevumiem pievienotā

7 Pieejams: https://www.routledge.com/ The-European-Handbook-of-Media-Accountability/Eberwein-Fengler-Karmasin/p/book/ 9781472457660 (26.10.2019.).

8 Pieejams: https://lvejo-online.eu/3680/medijiun-politika/3680 (26.10.2019.). vērtība - situācijas tvērums, analīzes dziḷums un formulējumu skaidrība - krietni atpaliek. Piem., noslēdzošā rekomendācija: "Mediju darbības tiesībnormu sakārtošana atbilstīgi pašreizējai realitātei." Tostarp tiek apiets tāds būtisks strukturālā konteksta jautājums: kāpēc lielākais laikraksts Latvijā iznāk nevis latviešu, bet krievu valodā (MK Latvija, turklāt lokalizēts Krievijas izdevums) un nedēlas laikraksti krievu valodā vispār ir trīs no Latvijas laikrakstu TOP 5? Šis apstāklis maldinoši ignorēts arī Latvijas mediju patēriṇa "vidējā" grozā (510. lpp. un uz grāmatas pēdējā vāka).

Ar nepārprotamām nostādnēm stāstu par strukturālo kontekstu toties labi papildina Skaidrītes Lasmanes nodaḷa par žurnālistu/mediju ētiku. Padzilinātu, uz pamatīgu izpēti balstītu ieskatu sniedz Ilzes Šulmanes un Lauras Uzules apakšnodaḷas par Latvijas žurnālistiem un mediju darbiniekiem, un Latvijas mediju vides raksturojumu pašu mediju darbinieku skatījumā. Piem., vērojums, ka "arvien vairāk uzskatu pretiškīibas parādās, ne tikai salīdzinot mediju, izteikumu autoru lietoto valodu, bet tās vērojamas arī vienas valodas ietvaros, tātad dalījums divās informācijas telpās pastāv samērā nosacīti”. Līdz ar to jāsecina, ka pašā latviešu žurnālistikā līdzās pastāv vismaz divas atškirīgas žurnālistikas kultūras, kas gan netiek nosauktas vārdā.

Grūtāk vērtēt Rolanda Tjarves sniegumu apakšnodaḷā par mediju īpašniekiem. No vienas puses, precīzas rekomendācijas un vērojumi, no otras - atsevišķas paviršības atsaucēs un datos, piem., AS Latvijas Mediji, kas izdod lielāko Latvijas dienas laikrakstu Latvijas Avìze, nav pat pieminēta (kā to var nepamanīt?). Tas pats raksturīgs autora nodaļai par Latvijas sabiedriskajiem medijiem, kurā vispār nav izmantoti citu autoru pētījumi par šo tēmu un lielākoties vērtīgie domugraudi mijas ar neatbilstībām. Piem., no $24 \%$ ziṇu un $19 \%$ analītisko raidījumu, kopā no $43 \%$ Latvijas Televīzijas budžeta sadalījumā, izsecinot apgalvojumu: "Pašreizējais finansējuma sadalījums vairāk atbilst valsts televīzijas statusam, kam jāgarantē vieta un laiks pie varas esošo eksponēšanai." Tikpat neargumentēts paliek arī cits ieteikums: "Kopumā LTV būtu svarīgi izsvērt oriǵinālraidījumu skaita samazināšanu vai pārvietošanu citā laikā, jo šobrīd 
prime time laikā no plkst. 19.00 līdz 22.00 tomēr pamatā dominē izklaides žanrs."

Toties Kārḷa Dagiḷa apakšnodaḷā par nacionālajiem komerciālajiem medijiem vērtīgākie ir apkopojošie secinājumi, kamēr nez kāpēc atkal tiek apieti nedēlas laikraksti krievu valodā un radio tirgus pētījums ${ }^{9}$, kā arī All Media Baltic nosaukts par lietuviešu (?!) pārvaldītu mediju uzņēmumu.

Uzteicama ir Sanitas Burķītes apakšnodaḷa par mediju saturu latgaliski, sevišķi par tendencēm un ietekmējošajiem faktoriem, lai gan izbrīnu rada tās ievietošana nodaḷā par Latvijas mediju formātu (?) daudzveidību un tas, ka tajā pašā laikā samērā lielais mediju segments krievu u. c. mazākumtautību valodās nemaz vienkopus nav aplūkots, kur nu vēl Latvijas mediji angliski.

\section{Terminoloǵisks brāḳis}

Te gribot negribot nonākam pie jautājuma par monogrāfijā, maigi sakot, nekonsekventi lietoto komunikācijas zinātnes terminologijiju. Pirmkārt jau - plašsaziṇas līdzekḷi. Pret šādu jēdziena apzīmējumu plašsaziņas (masu) mediju vietā pamatoti, principiāli un kategoriski iebilduši gan Inta Brikše, gan līdz šim visi citi latviešu komunikācijas zinātnieki, uzsverot, ka plašsaziṇas medijiem demokrātijā ir nevis instrumentāla, līdzekḷa, bet gan patstāvīga un centrāla loma (sal., piem.: Brikše, Inta: Komunikācija. Mediji. Universitāte. Rīga: Mansards, 2016, 43. 1pp.). Tātad reizi par visām reizēm: plašsaziņas mediji NAV līdzekḷi vai arī ir līdzekḷi TIKAI autoritārā politiskā un mediju sistēmā, resp., termins fundamentāli, pēc būtības neatbilst ar to apzīmētajam jēdzienam demokrātiskā sabiedrībā. Tikmēr šajā komunikācijas zinātnes monogrāfijā valodnieku un juristu ieviestais nepareizais termins, kādu arī citu Baltijas valstu valodās nelieto un no starptautiskajām zinātnes valodām vēl lieto tikai krievu valodā, pēkšņi un pirmoreiz bez kāda paskaidrojuma tiek plaši lietots.

Otrkārt, sociālie mediji - ar tiem saprotot sociālos tîklus (kā Facebook), video

9 Pieejams: https://neplpadome.lv/lv/assets/ documents/Petijumi/Radio_apraide_Latvija_2015_Jaunaka_versija.p $d f(26.10 .2019$.). koplietošanas platformas (kā Youtube) un meklēšanas rīkus (kā Google) internetā. Arī to loma monogrāfijā vienkopus nav apskatîta, kaut gan, tāpat kā mediju digitalizācija kopumā, ir izšksiroša Latvijas mediju vides daudzveidībai gan no reklāmas ieņēmumu, gan plašsaziņas mediju satura izplatīšanas viedokḷa. Arī nodaļā par mediju patēriņa daudzveidību un ekspozīciju zinātniskā redaktore nenodala sociālos medijus, tāpat kā e-pastu un e-komercijas vietnes, no plašsazinas medijiem (kā ziṇu portāliem) internetā un nosauc tikai eifēmiski: "Turklāt komunikācijas tehnologiiju plašais klāsts, kuru papildina nemit̄̄gi aizvien jaunāki formāti, kam ir liela nozīme cilvēku sociālā statusa, identitātes un dzīvesstila apliecinājumā, dạ̣ā sabiedrības ir kḷuvuši par dominējošo un pat vienīgo mediju satura lietošanas formātu." Visu cieņu autorei kā vēsturniecei, bet šeit vinna acīmredzot nav iekāpusi savās kurpēs.

Treškārt, formāts - tieši tādēḷ, lai nesanāktu "formātu formāts" (sk. iepriekšējo citātu), gan komunikācijas zinātnē, gan mediju nozares profesionālajā leksikā ir ieviesta dažādu mediju veidu tipoloǵija, proti, runa ir par mediju tipiem. Kā ievadā pareizi norādīts, atsaucoties uz H. Ševogu: "Aplūkojot televīzijas produktus, programmu un formātu daudzveidība." Tas pats attiecas uz radiostacijām, kā arī uz preses izdevumu tipogrāfisko formātu. Bet citādi nemētājamies ar formāta vārdu, arī veidojot nodaḷas virsrakstu - "Latvijas mediju formātu daudzveidība", kas neietver pēc nosaukuma sagaidāmo saturu, jo līdzās vēl lietots arī apzīmējums "daudzslāņaina vēstījuma formāts".

Tas pats, ceturtkārt, attiecas uz žanru, kas žurnālistikā un medijos ir satura pasniegšanas forma (informatīvie, viedokḷa žanri utt.), nevis mediju satura vai mediju produktu tips, kā tas pausts monogrāfijas nodaḷā "Mediju žanru daudzveidība". Piem., "mediji vīriešiem kā specifisks mediju žanrs", gan stilistiski, gan žanriski panākot negribētu komismu: "Pašpalīdzības stila raksti par sievietes seksualitāti .." Kāpēc, turklāt saprotamā kārtā nekonsekventi, bet pat apakšnodaļu nosaukumos jāievieš jauni, savdabīgi termini, ja tie nav labāki - īsāki un precīzāki - par nozarē jau lietotajiem, kā bērnu, sieviešu un vīriešu (grāmatā - mediji bērniem, sievietēm un vīriešiem), ezotēriskie (attiecīgi - misticisma, 
okultisma un dziedniecības) mediji, praktisko padomu (mājturības) mediji, galu galā - populārie iepretī kvalitātes medijiem, kas ir vai nu vispārēja rakstura - vispārējo interešu, vai specializētie - nozaru profesionālie un speciālo interešu mediji. Pie populārajiem medijiem visupirms pieder slavenību, privātās dzīves un tabloīdmediji (grāmatā attiecībā uz visiem šiem lietots apkopojošs apzīmējums "tabloīdmediji”, kas, kā attiecīgi nosauktā apakšnodạ̣ā atzīst pats tās autors Raivis Vilūns, īstenībā ir cits jēdziens - reizē šaurāks, jo nāk no attiecīga formāta avīzēm, un plašāks, jo sniedz arī sabiedriski politisku informāciju; Latvijā tam atbilst nedēḷas Kas Jauns Avīze un portāls Jauns.lv), kriminālziṇu (kriminālie) mediji un, visbeidzot, erotiskie un pornogrāfiskie (seksuāla atklāta satura) mediji. Tāpat kā nav grāmatā daudzkārt izmantoto "materiālu" žanru, bet ir publikāciju, tekstu u. tml. žanri.

Piektkārt, lai neputrotos, nav jājauc kopā vietējie (lokālie), reǵionālie un nacionālie mediji (nevis "pašmāju kino" (289. lpp.) un "pašmāju portāls Inbox" (503. lpp.)). Ne velti pēc apraides teritorijas Latvijā tie ir nodalīti arī Elektronisko plašsaziņas līdzekḷu likumā, un arī jēdzienu diferenciācijas logika saka priekšā, ka mūsu valstī reǵions sākas ar kādu no pieciem apgabaliem: Kurzeme, Zemgale, Vidzeme, Latgale un Rịga. Lìdz ar to maldinošs ir monogrāfijas apakšnodaḷas nosaukums "Regínālie mediji”, jo tā īstenībā vēsta galvenokārt par vietējiem medijiem, īstus reǵionālos, kā Kurzemes Radio, SIA Latgales regionālā televīzija un Vietējā Latgales Avīze, nez kāpēc atsevišķi pat neapskatot. Tāpat kā ir dienas (nevis ikdienas), nedēlas (nevis iknedēḷas) un mēneša (nevis ikmēneša) preses izdevumi, lai gan grāmatā tas daudzviet ir, tā sakot, viss viens ("vietējā sporta kanāla statusu ir ieguvis TV3", "lokāla mēroga sporta norises tiek atainotas reǵionālajos medijos", "vietējie ārzemju žurnālisti", "vietējie seriāli").

\section{Pētījuma (ne)laiks}

Lielākā problēma šim mediju pētìjumam, kas beidzot saṇēmis valsts finansējumu (pilnīga taisnība V. Zelčei, ka mediju pētniecība Latvijā "visai reti ir saņēmusi finansējumu no zinātnei atvēlētajiem valsts budžeta līdzekḷiem”), ir pētījuma laikaposms. Lai gan deklarēts kā tikai viens 2017. gads, kas vērtējams kā neapšaubāmi pārāk īss posms tendenču izpētei (šim nolūkam derētu vismaz desmit gadu periods), tas daudzviet ir visnotal nekonsekventi paplašināts, vienlaikus neietverot visu būtisko informāciju, tostarp no citu, ne tikai Latvijas Universitātes Komunikācijas studiju nodaḷas kolēğu publicētajiem pētījumiem, arī svešvalodās. Taču, publicējot datu blāķus par vairāk vai mazāk garu "tekošo momentu", tos dziḷāk un kvalitatīvi neinterpretējot un pat nepārbaudot (piem., par Dienu kā tirāžas ziņā lielāko latviešu valodā izdoto avīzi!). Diemžēl tas attiecas arī uz Raivja Vilūna nodaḷu par Latvijas mediju ziṇu ǵeogrāfiju. Kamēr Laurai Ardavai-Āboliņai nodaḷā par informācijas avotiem mediju 2017. gada populārākajos vēstījumos, izmantojot piemērotu pētījumu metodi, ir izdevies nonākt pie nozīmīgiem secinājumiem.

Savukārt visneveiksmīgākajā grāmatas nodaḷā par mediju tipolog̣iju, veicot kontentanalīzi tikai par trim 2017. gada mēnešiem, no aprīḷa līdz jūnijam, ir nonākts galvenokārt pie triviāla un šaura mediju satura apraksta, piem., apakšnodaḷā par bērnu medijiem pat nepieminot sabiedrisko mediju kopīgās interneta platformas LSM.lv Bērnistabu. Tai pašai autorei Maritai Zitmanei ievērojami labāk izdevusies apakšnodaḷa par sieviešu medijiem, argumentēti rekomendējot "plašāku un daudzveidīgāku sievietes reprezentāciju” tajos, bet vienlaikus pamatojuma pietrūcis apakšnodaḷā par dzimtes reprezentāciju Latvijas medijos, par ko jau sanemta kritika ${ }^{10}$.

Reprezentāciju daudzveidībai veltītajā nodaḷā sekmīgāk veicies Ojāram Skudram, Skaidrītei Lasmanei un Zanei Radzobei, kā arī Didzim Bērziņam attiecīgajās apakšnodaḷās par mediju politisko daudzveidību un žurnālistu praksēm, kultūras diskursu daudzveidību un marginalizēto sociālo grupu reprezentāciju Latvijas medijos.

Taču kopumā secinājumi bieži neizriet no pašiem tekstiem, tātad nav pamatoti ar pierādījumiem vai arī, gluži otrādi, dublējas ar secinājumiem tekstā. Atsevišķo tekstu ievadi un atsauces uz literatūru tajos lielākoties ir

10 Pieejams: http://www.la.lv/viriesu-skaitisana (26.10.2019.). 
formālas, izskatās kā mākslīgi piekabinātas. Pēc principa - vajag taču pielikt kaut kādu teoriju, nevis - tiešām ievērot noteiktu konceptuālu skata punktu.

Nemaz nerunājot par vairākiem valodas negludumiem (arī neprecizitātēm nosaukumos) un atsauču trūkumiem, tomēr nevar nepieminēt svešvalodu nosaukumu rakstību angliski amerikāniskā, nevis starptautiskā transkripcijā, pēc kuras, sekojot katrai rakstu zīmei, iespējams atjaunot rakstību orig̣inālvalodā (tātad, piem., nevis Domskaya ploshchad, bet gan Domskaja ploščad').
Galvenais, grāmatai tiešām nāktu par labu, ja tā būtu plānāka, neizplūdusi, vienlaikus koncentrējot Latvijas komunikācijas zinātnei pieejamos naudas un cilvēku resursus un sadarb̄̄ibā koncentrējoties uz reālajām mediju daudzveidības problēmām, kas, kā jau minēts, tagad palikušas tikai daḷēji iezīmētas. Kā pravietiski noslēdzas pēdējā nodaḷa par recepcijas kontekstu: "Pētījumu pārorientācija no satura un formas daudzveidības uz mediju ekspozīcijas un tās formu kvantitatīvu un kvalitatīvu analīzi." 